\title{
磁場中熱処理した $\mathrm{Bi}_{2} \mathrm{Sr}_{2} \mathrm{CaCu}_{2} \mathrm{O}_{8}$ 線材の電流輸送特性
}

\author{
井上 拓士 ${ }^{* 1}$, 淡路 智 ${ }^{* 1, \dagger}$, 高橋 健一郎 ${ }^{* 2}$, Petre BADICA $^{* 3}$, \\ 西島 元 $^{* 1}$, 渡辺 和雄 ${ }^{* 1}$
}

\section{Transport Properties of $\mathrm{Bi}_{2} \mathrm{Sr}_{2} \mathrm{CaCu}_{2} \mathrm{O}_{8}$ Materials with In-field Heat-treatment}

\author{
Takushi INOUE ${ }^{* 1}$, Satoshi AWAJI $^{* 1}$, Ken-ichiro TAKAHASHI ${ }^{* 2}$, Petre BADICA $^{* 3}$, \\ Gen NISHIJIMA $^{* 1}$ and Kazuo WATANABE ${ }^{* 1}$
}

\begin{abstract}
Synopsis: The transport properties for in-field heat-treated monocore and multicore $\mathrm{Bi}_{2} \mathrm{Sr}_{2} \mathrm{CaCu}_{2} \mathrm{O}_{8}(\mathrm{Bi} 2212)$ tapes and multicore Bi2212 round wires were measured in detail. We found that the in-field heat-treatment enhances not only the critical current density $J_{\mathrm{c}}$ but also the $n$-value for all samples used in this study. These enhancements for the monocore tapes were more remarkable, compared in those of the multicore tapes and wires. Therefore the in-field heat-treatment is more effective for the Bi2212 tapes with a large core size. Microstructure observation shows that the grain size of the monocore tapes decreases as the result of in-field heat treatment. The analysis based on the percolation model related to the local $J_{\mathrm{c}}$ distribution suggests that the in-field heat-treatment increases the $m$ value, which determines the shape of the local $J_{\mathrm{c}}$ distribution and is related to the $n$-values. The two $J_{\mathrm{c}}$ distribution model can explain that the increases in $n$ - and $m$-values are due to the decreases in the aspect ratio of the grains during in-field heat treatment.
\end{abstract}

Keywords: critical current density, $E-J$ property, $n$-value, in-field heat-treatment, percolation model

\section{1. はじめに}

銀被覆 $\mathrm{Bi}_{2} \mathrm{Sr}_{2} \mathrm{CaCu}_{2} \mathrm{O}_{8}(\mathrm{Bi} 2212)$ 線材は低温において強磁 場中での臨界電流密度特性が高いことから，20 K 以下で 用いる強磁場発生用線材として期待されている。最近では 米国フロリダの国立強磁場研究所が, Bi2212 インサート コイルを作製し $19.94 \mathrm{~T}$ のバックアップ磁場中で組み合わ せ磁場として $25.05 \mathrm{~T}$ の発生に成功している ${ }^{1)}$. しかし, その $n$ 值は金属系超伝導材料と比べて低い值に留まってい ることが問題の一つとして残っている．特に NMR マグ ネットにおいては, 低い $n$ 值は永久電流運転する際の深刻 な問題となる.

一方, 結晶配向性を高める事により $J_{\mathrm{c}}$ を向上させる手 段のひとつとして強磁場中で結晶成長させる方法がある ${ }^{2)}$. 銅酸化物超伝導体の場合, 結晶構造の異方性が大きく, $c$

Received May 9, 2008

*1 東北大学金属材料研究所 強磁場超伝導材料研究センター 干 980-8577 宮城県仙台市青葉区片平 2-1-1

HFLSM, IMR, Tohoku University, Katahira 2-1-1, Aoba-ku, Sendai, Miyagi 980-8577, Japan.

*2 物質・材料研究機構 超伝導材料センター

干305-0047 茨城県つくば市千現 1-2-1

Superconducting Materials Center, NIMS, Sengen 1-2-1, Tsukuba, Ibaraki 305-0047, Japan

*3 National Institute of Materials Physics, Bucharest-Magurele, POB MG-7, 077125, Romania.

† E-mail: awaji@imr.tohoku.ac.jp
軸方向と $a b$ 軸方向で様々な物性值に差があり, 磁化率に おいても結晶方位に対する異方性がある ${ }^{3)}$. 特に, Bi2212 超伝導体は結晶構造の異方性が大きく, その線材では部分 溶融一徐泠法によって液相との共存状態で結晶成長が行わ れるため, 結晶粒が動きやすい環境にあり, 強磁場中配向 育成に適した材料であると考えられる。

本研究では, 線材構造の異なる種々の銀被覆 Bi2212 線 材に対して磁場中熱処理を行い, 超伝導特性の向上, 磁場 中熱処理が微細組織と電界一電流密度特性（E-J 特性）に 及ぼす影響, 及びその解明を目的として, Bi 系線材にお ける電流輸送特性の観点から議論する。

\section{2. 実験方法}

\section{1 銀被覆 Bi2212 線材}

単芯線として, 昭和電線ケーブルシステム（株） （SWCC） から提供された外径 $3 \mathrm{~mm}$, 内径 $2 \mathrm{~mm}$ の銀被 覆単芯丸線を用い, 線引き・圧延加工を行うことにより, 幅が $3 \mathrm{~mm}$, 厚みが $0.23 \mathrm{~mm}, \mathrm{Bi} 2212$ 層の厚みが $100 \mu \mathrm{m}$ の未熱処理の単芯テープを作製した。作製行程は，物質材 料研究機構(NIMS)の線引き・圧延装置を用いて行った。 この線材は SEM やX 線ディフラクトメーターなどを用い た微細組織の評価が容易なため, 磁場中熱処理による微細 組織の変化と, その $E-J$ 特性との関連についての議論に用 いた。 


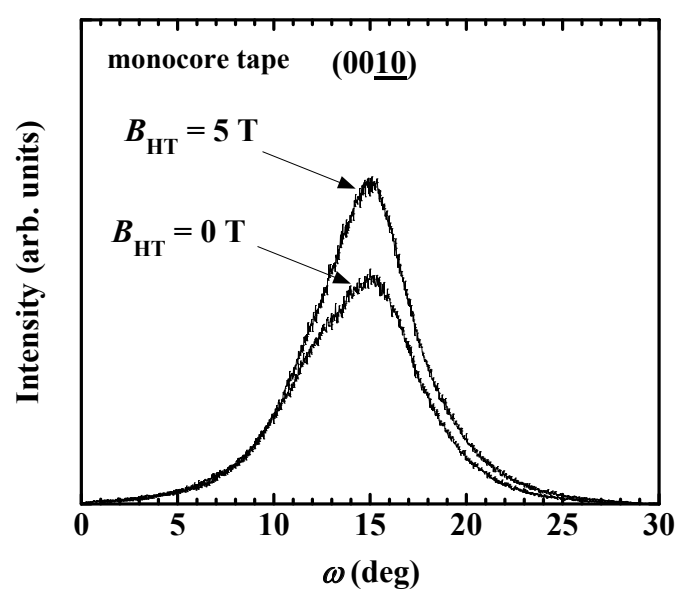

Fig. 1 Rocking curve of (0010) for the interface to $\mathrm{Ag}$ of the monocore tapes.

さらに, 多芯線試料として SWCC より提供の未熱処理 の銀被覆 Bi2212 多芯丸線及び多芯テープを用いた. 多芯 丸線は直径 $0.81 \mathrm{~mm}$, フィラメント数 427 本, 銀比が 3 の 線材である．尚，参考試料として線材構成が同様の，市販 されている SWCC 製の熱処理済多芯丸線（0 T 中熱処理） を準備した。多芯テープは幅 $40 \mathrm{~mm}$, 厚み $0.34 \mathrm{~mm}$, フィラメント数 61 本, 銀比が 2 のテープである.この 2 つの試料ともにフィラメント層の厚みは $10-20 \mu \mathrm{m}$ 程度で ある。

\section{2 磁場中熱処理方法}

東北大学金属材料研究所強磁場超伝導材料研究センター にある $8 \mathrm{~T}$ 冷凍機冷却超伝導マグネットに組み込まれた強 磁場中で熱処理可能な電気炉を用い，0 $\mathrm{T}$ 及び $5 \mathrm{~T}$ 中で部 分溶融一徐冷法により熱処理を行った．用いた熱処理炉の 内径による制限のため，熱処理を行う線材はすべて $30 \mathrm{~mm}$ とした。熱処理時の磁場 $\left(B_{\mathrm{HT}}\right)$ は多芯丸線では印加方向を 分かるようにし, 多芯, 単芯テープの場合は, テープ面に 垂直に印加した。 Bi2212 バルクやテープを磁場中で溶融 凝固した場合には，平板結晶に垂直な $\mathrm{c}$ 軸が磁場方向に揃 う事が報告されている ${ }^{2,4)}$ 。これは，序論で述べたように 主に常磁性の異方性に起因している ${ }^{3)}$. したがって，テー プ面に垂直に磁場を印加した場合は，平板状 Bi2212 結晶 粒の $c$ 軸がテープ面に垂直に配向成長することが期待さ れる. 磁場中熱処理を行う際は, 室温で目的の磁場まで磁 場を増加させた後, 酸素雰囲気中で熱処理を行い, 熱処理 終了後, 試料が室温程度まで泠えてから磁場を下げた。

\section{3 試料評価}

銀被覆 Bi2212 単芯テープについては SEM による組織観 察，及び X 線回折により組織の結晶性の評価を行った. このとき，銀シースを機械的に剥がすことにより超伝導層 界面を直接測定した。

$E-J$ 特性の測定には直流四端子法を用い，試料は GM 冷 凍機冷却温度可変クライオスタットに取り付けた。試料長
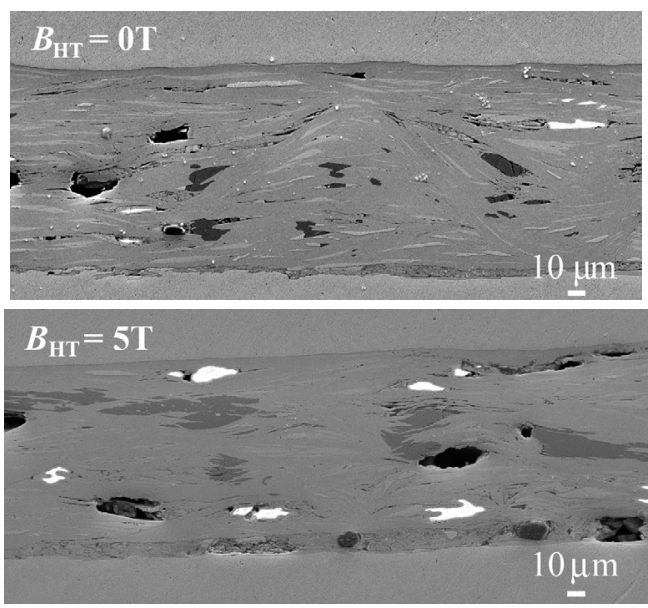

Fig. 2 SEM images of the longitudinal cross-section of the monocore tapes.

さは, 熱処理したままの $30 \mathrm{~mm}$ であり, 電圧端子間距離 を $10 \mathrm{~mm}$ とした。このクライオスタットを $15 \mathrm{~T}$ 冷凍機冷 却超伝導マグネットと組み合わせ，最大 $14 \mathrm{~T}$ までの外部 磁場 $\left(B_{\mathrm{ext}}\right)$ を各々の試料の $B_{\mathrm{HT}}$ 方向と平行に印加した. 試 料電流源には大電流通電によるジュール発熱の影響を少な くするためパルス電流源を用い, 最大電流值を $200 \mathrm{~A}$ とし $た^{5)}$. 得られた $E-J$ 特性の結果から， $J_{\mathrm{c}}$ は $1 \mu \mathrm{V} / \mathrm{cm}$ の電界 基準, $n$ 值は $10^{-5}$ から $10^{-6} \mathrm{~V} / \mathrm{cm}$ の範囲で決定した.

\section{3. 実験結果と考察}

\section{1 単芯テープの組織評価}

0T 及び $5 \mathrm{~T}$ で熱処理した単芯テープ線材の銀の剥離後の Bi2212 界面に対する(0010)面に対するロッキングカーブを
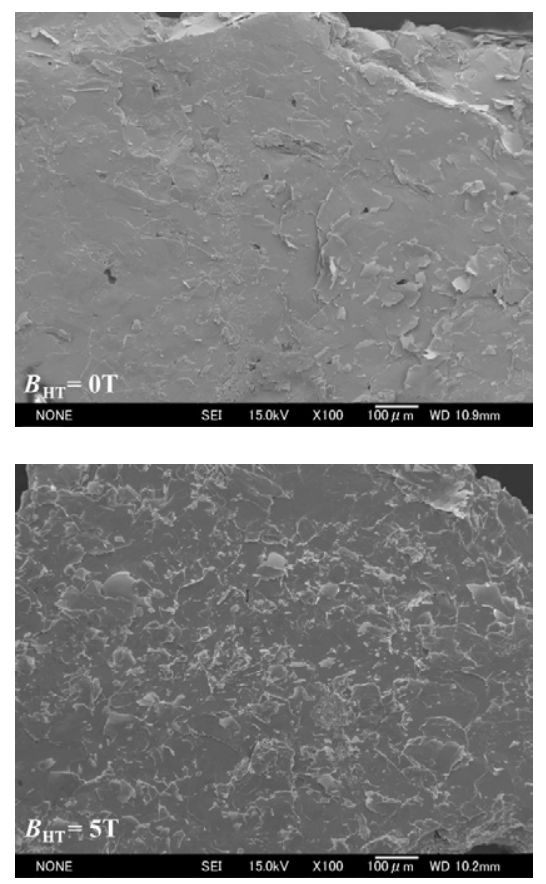

Fig. 3 SEM images of the interface to Ag of the monocore tapes. 


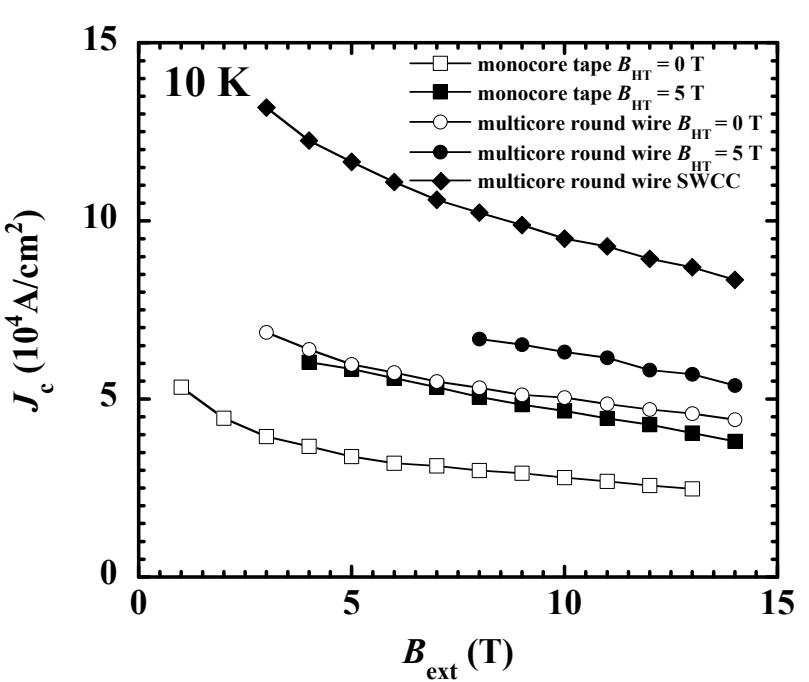

Fig. 4 Magnetic field dependence of $J_{\mathrm{c}}$ at $10 \mathrm{~K}$ for the multicore round wires and monocore tapes.

Fig. 1 に示す. $B_{\mathrm{HT}}=0 \mathrm{~T}$ で熱処理した試料においては半值 幅が $7.0^{\circ}, B_{\mathrm{HT}}=5 \mathrm{~T}$ で熱処理した試料は $5.8^{\circ}$ となった。単 芯テープの Bi2212 コアの厚みは約 $100 \mu \mathrm{m}$ であるが，X 線 の侵入深さが数 $\mu \mathrm{m}$ 程度なので, この結果は銀との界面近 傍の情報のみが反映していると考えられる。したがって, 磁場中熱処理により銀界面付近での $c$ 軸配向性が向上した ことが示唆される.

Fig. 2 に単芯テープにおける試料長手方向に対する断面 組織の SEM 像を示す. $B_{\mathrm{HT}}=0 \mathrm{~T}$ で熱処理した試料では, 銀との界面付近は Bi2212 結晶粒（図中で薄い灰色）が良 く配向成長しているが，中心部分は配向が乱れている事が 分かる。また試料全体にわたって非超伝導相（Cu-rich 相 (図中の濃い灰色)，Bi-rich 相 (図中の白色)）も多く見 られる. $B_{\mathrm{HT}}=5 \mathrm{~T}$ で熱処理した試料でも, 試料内部に非 超伝導相が多く見られるが，中心部分においても Bi2212 結晶粒が良く $c$ 軸配向している。これは，結晶成長過程 において, 磁場配向効果によって線材中心部分でも Bi2212 結晶粒の $c$ 軸が磁場と平行に揃うことで良く $c$ 軸 配向したためであると考えられる.

Fig. 3 に単芯テープの銀界面における組織の SEM 像を 示す. $B_{\mathrm{HT}}=0 \mathrm{~T}$ で熱処理した試料の界面組織は，良く溶 融成長した場合の平板状の Bi2212 結晶粒が観測された. 一方, $B_{\mathrm{HT}}=5 \mathrm{~T}$ で熱処理した試料の表面組織は, 平板状 の Bi2212 結晶粒が観測されるものの, 前者と比較して細 かい小さな結晶粒が観測され，その形状も複雑に変化して いることが分かる.これは Bi2212 に対する磁場中熱処理 効果は磁場配向効果だけではなく, Bi2212 結晶粒を微細 化する効果も持つことを示している.

\section{$3.2 J_{c}$ 特性及び $n$ 値}

Fig. 4 に多芯丸線及び単芯テープの $10 \mathrm{~K}$ における $J_{\mathrm{c}}$ の $B_{\text {ext }}$ 依存性を示す. 多芯丸線及び単芯テープ共に磁場中熱

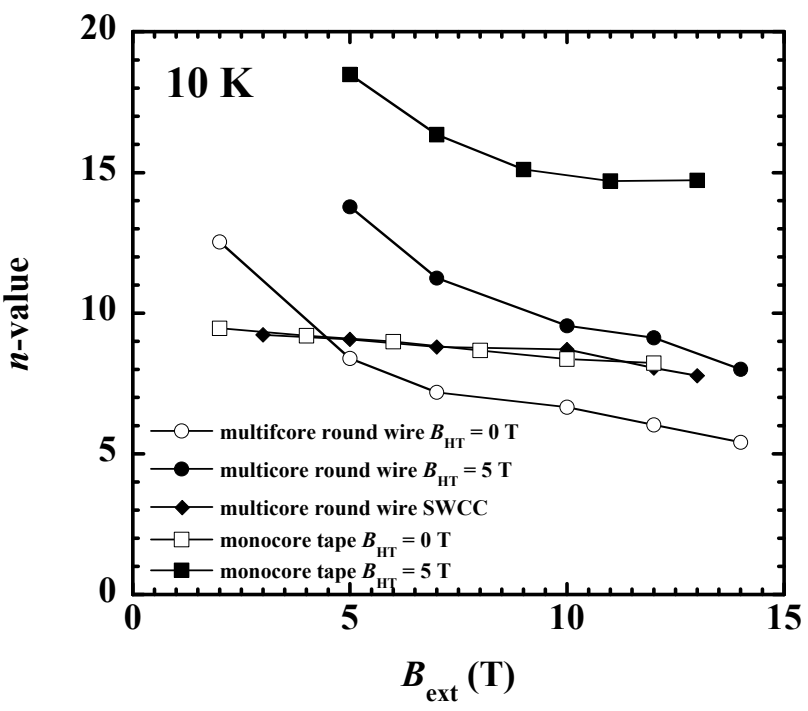

Fig. 5 Magnetic field dependence of $n$-value at $10 \mathrm{~K}$ for the multicore round wires and monocore tapes.

処理によって $J_{\mathrm{c}}$ が向上したことが分かる. また， $B_{\mathrm{HT}}=5$ $\mathrm{T}$ で熱処理した単芯テープ試料の $J_{\mathrm{c}}$ は多芯丸線の $B_{\mathrm{HT}}=0$ $\mathrm{T}$ で熱処理した試料の $J_{\mathrm{c}}$ に匹敵している.さらに, 磁場 中熱処理による単芯テープの $J_{\mathrm{c}}$ の向上は多芯丸線の $J_{\mathrm{c}}$ の 向上よりも顕著である.これは磁場中熱処理が超伝導層の 厚い線材に対してより効果が高いこと意味している．ここ で最も高い $J_{\mathrm{c}}$ を示した SWCC 試料は, 電気炉も含めて最 も最適化した熱処理条件で作製されていると考えられる. この值が，多芯化による Bi2212 フィラメント厚みの減少 と最適化熱処理による高い配向性の結果とすると, 最適化 された熱処理条件で作製した多芯テープでは, 磁場中熱処 理による $J_{\mathrm{c}}$ の向上が起きない可能性がある. しかし, 次 に述べるように, $n$ 值に関しては, 磁場中熱処理による 向上が期待できる.

Fig. 5 に多芯丸線及び単芯テープの $10 \mathrm{~K}$ における $n$ 值 の磁場依存性を示す.ここで, 測定時に印加した磁場は, 熱処理中に印加した磁場と区別するため $B_{\text {ext }}$ と標記する. 磁場中熱処理した試料の $n$ 值はゼロ磁場で熱処理した試 料よりも大幅に向上している. 一般に $n$ 值は $J_{\mathrm{c}}$ の向上 伴って増加する事が知られている. しかし, 磁場中熱処理 した多芯丸線試料は, 最も高い $J_{\mathrm{c}}$ を示した SWCC 試料よ りも高い值を示すことが分かった。このことは，磁場中熱 処理が配向性の向上による $J_{\mathrm{c}}$ の増加だけでなく, 試料の $n$ 值を向上させるのに有効な手段であることを示唆してい る $^{7)}$.

\section{4. パーコレーションモデル及び二方向電流分布 モデルに基づいた解析}

磁場中熱処理による $J_{\mathrm{c}}$ の向上は，主に磁場配向効果によ る配向性の向上によると考えられる. しかし, Fig. 4, 5 で 


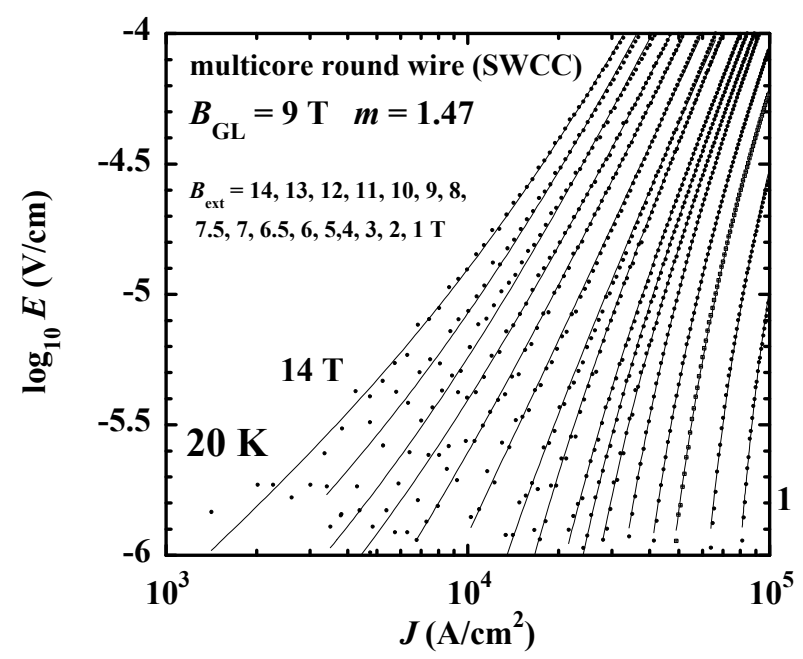

Fig. 6 Examples of the fitted result of $E-J$ properties for the SWCC sample using the peroration model.

見られたように， $J_{\mathrm{c}}$ の向上以上に $n$ 值が向上する点は磁場 配向効果だけでは説明できない。そこで，その機構を以下 に述べる電界-電流密度特性（ $E-J$ 特性）を局所臨界電流密 度の分布モデル (パーコレーションモデル) ${ }^{6)}$ と 2 方向電 流分布モデル ${ }^{7)}$ にっって解析を行うことで， $n$ 值の向上に ついて考察する。

パーコレーションモデルでは, 局所 $J_{\mathrm{c}}$ 分布を次式で示さ れる Weibull 関数を用いて表す。

$$
P\left(J_{\mathrm{cl}}\right)=\frac{m}{J_{0}}\left(\frac{J_{\mathrm{cl}}-J_{\mathrm{cm}}}{J_{0}}\right)^{m-1} \exp \left\lfloor-\left(\frac{J_{\mathrm{cl}}-J_{\mathrm{cm}}}{J_{0}}\right)^{m}\right\rfloor
$$

ここで, $J_{\mathrm{cl}}, J_{\mathrm{cm}}, J_{0}$ はそれぞれ局所 $J_{\mathrm{c}}$, 局所 $J_{\mathrm{c}}$ 分布の最小 值，局所 $J_{\mathrm{c}}$ 分布の幅であり， $m$ は分布の形を決めるパラ メータである。このとき，E-J 特性は，パーコレーション 転移磁場 $B_{\mathrm{GL}}$ あるいは転移温度 $T_{\mathrm{GL}}$ を境として以下の 3 つ の式で表現される ${ }^{6)}$.

$$
\begin{array}{ll}
E(J)=\frac{\rho_{\mathrm{FF}}}{m+1} J\left(\frac{J}{J_{0}}\right)^{m}\left(1-\frac{J_{\mathrm{cm}}}{J}\right)^{m+1} & \left(B<B_{\mathrm{GL}}\right), \\
E(J)=\frac{\rho_{\mathrm{FF}}}{m+1} J\left(\frac{J}{J_{0}}\right)^{m} & \left(B=B_{\mathrm{GL}}\right), \\
E(J)=\frac{\rho_{\mathrm{FF}}}{m+1} \mid J_{\mathrm{cm}}\left(\frac{\left|J_{\mathrm{cm}}\right|}{J_{0}}\right)^{m}\left\{\left(1+\frac{J}{\left|J_{\mathrm{cm}}\right|}\right)^{m+1}-1\right\} & \left(B>B_{\mathrm{GL}}\right) .
\end{array}
$$

ここで， $\rho_{\mathrm{FF}}$ は磁束フロー抵抗である.このモデルでは, 広い温度・磁場領域で $E-J$ 特性を精度良く記述できること が知られている。

Fig. 6 に, SWCC 試料の $20 \mathrm{~K}$ における $E-J$ 特性に対す るパーコレーションモデルによるフィッティング結果を例 として示す. 磁場の増加に伴って $E-J$ 曲線は高電流側から 低電流側へシフト寸ると共に，上凸から直線を経て下凸へ と変化していることが分かる。図中の実線がパーコレー ションモデルに基づくフィッティング結果である。このモ デルが広い電界範囲にわたって実験結果をよく再現してい る事が分かる。ここで，E-J 特性が直線となるところで パーコレーション転移磁場 $B_{\mathrm{GL}}$ を決定した。 Fig. 7 に 種々の試料の $B=B_{\mathrm{GL}}$ での局所的 $J_{\mathrm{c}}$ の確率密度分布 $P\left(J_{\mathrm{cl}}\right)$ を 示す. 局所 $J_{\mathrm{c}}$ 分布は, 単芯テープと比べて, 多芯線材で より非対称な形状となっており $m$ 值が小さいことが分か る.さらに，種々の試料について磁場中熱処理によって $m$ 值が向上し, その分布幅 $J_{0}$ もブロードになることが分 かった. $m$ 值は $P\left(J_{\mathrm{cl}}\right)$ の形を表す量であり, 大きい場合は 局所的 $J_{\mathrm{c}}$ 分布の形は対称的な形となる. また, $m$ 值は超 伝導一常伝導転移の鋭さを示す $n$ 值と相関がある. 例え ば，(2)式から $B=B_{\mathrm{GL}}$ では $n=m+1$ となる. $m$ 值が大きい と, $n$ 值が大きいことに対応してこの転移は鋭い転移とな る. したがって, 磁場中熱処理によって $m$ 值が増大し, そのことが $n$ 值の向上と深く関連を持つことが示唆され $ろ^{8,9)}$.

しかし，この結果からだけでは磁場中熱処理による局所 $J_{\mathrm{c}}$ 分布の変化と微細組織との関連性は説明できない。そこ
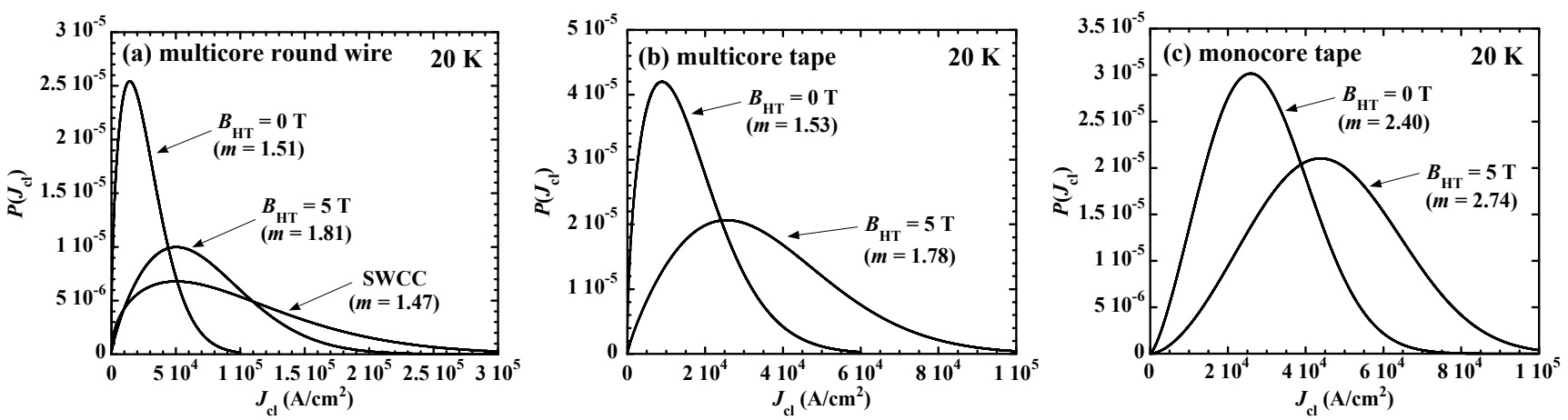

Fig. 7 Local $J_{\mathrm{c}}$ distribution at $B_{\mathrm{GL}}$ for (a) multicore round wires, (b) multicore tapes and (c) monocore tapes. 
Table 1 Parameters obtained at $20 \mathrm{~K}$ and $B_{\mathrm{GL}}$ for B//c evaluated by the two-directional $J_{\mathrm{c}}$ distribution model

\begin{tabular}{|c|c|c|c|c|c|c|c|c|c|}
\hline Sample & $B_{\mathrm{HT}}(\mathrm{T})$ & $B_{\mathrm{GL}}(\mathrm{T})$ & $\sigma_{\mathrm{ab}}$ & $\sigma_{\mathrm{c}}$ & $J_{\mathrm{cl}}^{\mathrm{ab}}\left(10^{4} \mathrm{~A} / \mathrm{cm}^{2}\right)$ & $J_{\mathrm{cl}}{ }^{\mathrm{c}}\left(10^{4} \mathrm{~A} / \mathrm{cm}^{2}\right)$ & $J_{\mathrm{cl}}{ }^{\mathrm{c}} / J_{\mathrm{cl}}^{\mathrm{ab}}$ & $m$ & $n$ \\
\hline \multirow{3}{*}{$\begin{array}{l}\text { Multicore } \\
\text { round wire }\end{array}$} & 0 (SWCC*) & 9 & 3.43 & 6.26 & 4.40 & 11.2 & 2.56 & 1.47 & 2.47 \\
\hline & 0 & 9 & 0.92 & 1.65 & 1.23 & 3.04 & 2.47 & 1.51 & 2.51 \\
\hline & 5 & 7 & 2.44 & 3.91 & 4.00 & 8.40 & 2.10 & 1.81 & 2.78 \\
\hline \multirow{2}{*}{ Multicore tape } & 0 & 9 & 0.56 & 0.99 & 0.76 & 1.85 & 2.43 & 1.53 & 2.50 \\
\hline & 5 & 7 & 1.19 & 1.87 & 2.02 & 4.14 & 2.05 & 1.78 & 2.97 \\
\hline \multirow{2}{*}{ Monocore tape } & 0 & 5.5 & 0.90 & 1.18 & 1.97 & 3.38 & 1.72 & 2.40 & 3.40 \\
\hline & 5 & 5.5 & 1.37 & 1.65 & 3.34 & 5.36 & 1.60 & 2.74 & 3.74 \\
\hline
\end{tabular}

* SWCC: heat-treated at SWCC

で，個々の試料についてパーコレーションモデルに基づく 解析から得られた $P\left(J_{\mathrm{cl}}\right)$ に対し, 試料の微細組織と異方性 を考えて，二つのガウス分布関数の和の形で表される二方 向電流分布モデル 7)を用いて解析を行った。 このモデルで はパーコレーションモデルにより評価された $\mathrm{P}\left(J_{\mathrm{cl}}\right)$ を $a b$ 面 内方向と $c$ 軸方向の二つの寄与に分離することで，結晶粒 のアスペクト比の違いを二つの局所 $J_{\mathrm{c}}$ 分布によって取り 込むことができる。

$$
P\left(J_{c l}\right)=I \frac{1}{\sqrt{2 \pi} \sigma_{a b}} \exp \left(-\frac{\left(J_{c l}-J_{c l}^{a b}\right)^{2}}{2 \sigma_{a b}{ }^{2}}\right)+O \frac{1}{\sqrt{2 \pi} \sigma_{c}} \exp \left(-\frac{\left(J_{c l}-J_{c l}^{c}\right)^{2}}{2 \sigma_{c}^{2}}\right)
$$

ここで， $\sigma_{\mathrm{ab}}$ 及び $\sigma_{\mathrm{c}}$ はそれぞれ $a b$ 面と $c$ 軸方向の電流分 布の分散, $J_{\mathrm{cl}}^{\mathrm{ab}}$ と $J_{\mathrm{cl}}{ }^{\mathrm{c}}$ はそれぞれの分布の中心, $I$ 及び $O$ はその割合である。したがって， $I+O=1$ の関係がある. $E-J$ 特性から得られた $\mathrm{P}\left(J_{\mathrm{cl}}\right)$ に対して二方向電流分布モデ ルの (3) 式を用いてフィッティングを行った。ここで, $\mathrm{P}\left(J_{\mathrm{cl}}^{\mathrm{ab}}\right)$ と $\mathrm{P}\left(J_{\mathrm{cl}}{ }^{\mathrm{c}}\right)$ の割合を表す係数 $I, O$ について, 全ての 試料に対して $I: O=0.4: 0.6$ とした場合が良くフィットし たので，この值に固定して，4 つのフィッティングパラ メータを用いて解析を行った。

Fig. 8 に局所 $J_{\mathrm{c}}$ 分布の形が最も非対称であった SWCC

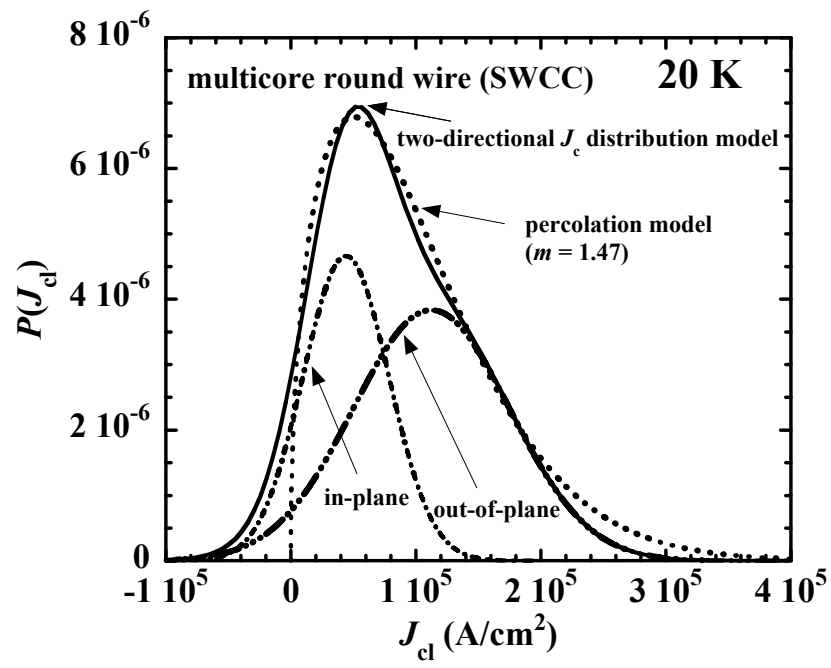

Fig. 8 Local $J_{\mathrm{c}}$ distribution at $20 \mathrm{~K}, 9 \mathrm{~T}$ and its double Gaussian-fitted result.
試料の $20 \mathrm{~K}, B_{\mathrm{GL}}$ での $\mathrm{P}\left(J_{\mathrm{cl}}\right)$ に対する二方向電流分布モデ ルを用いたフィッティング結果を示す。ここではガウス分 布関数を用いているために, Weibull 関数を用いた場合と 比心゙て低 $J_{\mathrm{cl}}$ 側に裾を引いているが，それ以外の部分では すべての結果に対して良い一致が得られていることが分か る.このテールの部分の $E-J$ 特性への影響を調べるため に, Weibull 関数で表される $\mathrm{P}\left(J_{\mathrm{cl}}\right)$ を電流密度 $J$ について 二回積分して計算した $E-J$ 特性と, (3)式の二つのガウス 分布関数の和で表される $\mathrm{P}\left(J_{\mathrm{cl}}\right)$ を同様に計算して得られた $E-J$ 特性を比較する. Fig. 9 に $B_{\mathrm{GL}}$ における計算した $E-J$ 特性と実際の測定データの結果を示す。これから, Weibull 関数も二方向電流分布モデルも実験結果をよく再 現しており, ガウス分布による低 $J_{\mathrm{c}}$ 側の裾の影響は, 非 常に低い電界領域にのみ影響するが，測定領域では問題に ならない事が分かる.

Table 1 に各々の試料の $\mathrm{P}\left(J_{\mathrm{cl}}\right)$ について二方向電流分布モ デルによる解析から得られたフィッティングパラメータを 示す. 種々の試料における分散 $\sigma_{\mathrm{ab}}, \sigma_{\mathrm{c}}$ は, 磁場中熱処理 した試料の方がゼロ磁場で熱処理した試料よりも大きく, 絶対值としては SWCC 試料が最も大きかった。これは, 二方向電流分布モデルにおける分散のが $\mathrm{P}\left(J_{\mathrm{cl}}\right)$ の分布幅 $J_{0}$

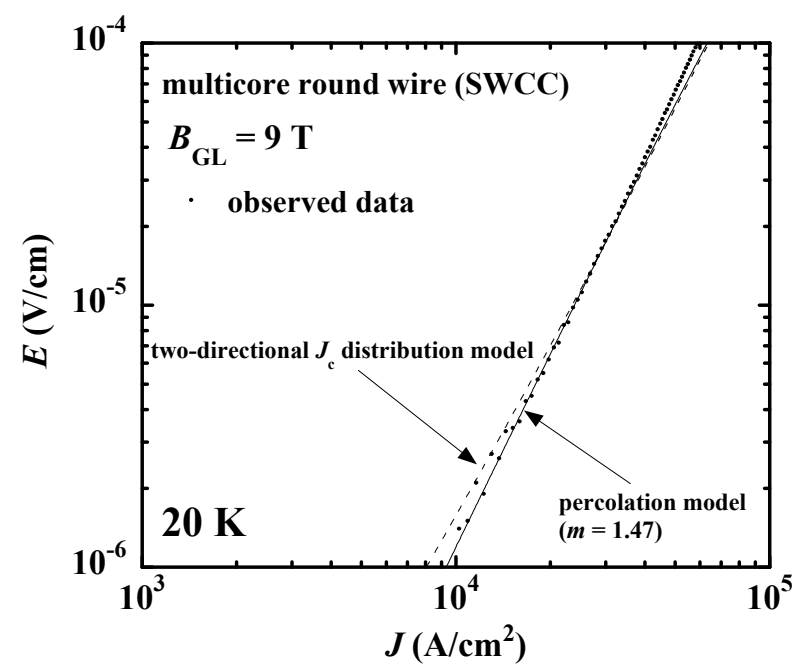

Fig. 9 Comparison of the $E-J$ properties between the percolation and two-directional $J_{\mathrm{c}}$ distribution models. 
と対応しており， $J_{0}$ が大きい試料ほど $\sigma_{\mathrm{ab}}, \sigma_{\mathrm{c}}$ が大きくな ることを意味している。また，最も高い $J_{\mathrm{c}}$ 特性を示す SWCC 試料の $J_{\mathrm{cl}}^{\mathrm{ab}}$ 及び $J_{\mathrm{cl}}^{\mathrm{c}}$ の絶対值は他の全ての試料より も高い值を示している。この試料は個々の結晶粒の配向が 良く，かつ非常に密に充填されているため，結晶粒同士の 結合性は非常に良いと考えられる。そのために粒界におけ る $J_{\mathrm{c}}$ が非常に大きくなったと考えられる。また，種々の 線材に対して $B_{\mathrm{HT}}=5 \mathrm{~T}$ で熱処理した試料の $J_{\mathrm{cl}}{ }^{\mathrm{ab}}$ 及び $J_{\mathrm{cl}}{ }^{\mathrm{c}}$ は $B_{\mathrm{HT}}=0 \mathrm{~T}$ で熱処理した試料と比較して高い值を示し た。これは磁場配向効果で結晶粒が良く配向し，その結果 として結晶粒同士の結合性が向上したため，粒界における $J_{\mathrm{c}}$ が大きくなったと考えられる.さらに， $J_{\mathrm{cl}}{ }^{\mathrm{c}} / J_{\mathrm{cl}}{ }^{\mathrm{ab}}$ と $m$ 值 に逆の相関があることが分かる。(2)式から E-J 特性にお ける $n$ 值は $m$ 值と正の相関があることが示されている. したがって, 磁場中熱処理による $n$ 值の増大は, $J_{\mathrm{cl}}{ }^{\mathrm{c}} / J_{\mathrm{cl}}{ }^{\mathrm{ab}}$ の減少による $m$ 值の増加に基づいていることが分かる. 定義により $J_{\mathrm{cl}}{ }^{\mathrm{ab}}$ 及び $J_{\mathrm{cl}}{ }^{\mathrm{c}}$ は $a b$ 面方向と $c$ 軸方向の $\mathrm{P}\left(J_{\mathrm{cl}}\right)$ の ピーク值に相当する． 2 方向電流分布モデルでは， $a b$ 面 方向と $\mathrm{c}$ 軸方向の局所臨界電流密度 $J_{\mathrm{cl}}^{\mathrm{ab}}, J_{\mathrm{cl}}{ }^{\mathrm{c}}$ の関係は, 結 晶粒の厚み $D$ 及び長さ $2 L$ を用いて以下のように表現され $3^{8)}$.

$$
J_{c l}=J_{c l}^{a b}+J_{c l}^{c}=J_{c l}^{G B}\left(1+\frac{L}{100 D}\right)
$$

ここで， $J_{\mathrm{cl}}^{\mathrm{GB}}$ は結晶粒界臨界電流密度であり，単純化 のために $\mathrm{ab}$ 方向が $\mathrm{c}$ 軸方向の 100 倍と仮定した（文献 7 では等しいとしてある)。ここで重要なのは， $J_{\mathrm{cl}}{ }^{\mathrm{c}}$ がアスペ クト比 $\mathrm{L} / \mathrm{D}$ の関数となっている点である. すなわち, 平 板結晶のアスペクト比が大きくなると, c 軸方向に流れる 局所臨界電流密度である $J_{\mathrm{cl}}{ }^{\mathrm{c}}$ はその有効断面積が増大寸る ことによって増加する。 その結果, 平板結晶のアスペクト 比が大きくなると, $J_{\mathrm{cl}}{ }^{\mathrm{c}} / J_{\mathrm{cl}}{ }^{\mathrm{ab}}$ の比も増大し, 結果として局 所 $J_{\mathrm{c}}$ 分布が非対称な形となる。このため, 十分溶融成長 した SWCC 線材では, 高い $J_{\mathrm{c}}$ が得られる一方で, 局所 $J_{\mathrm{c}}$ 分布の形が非対称となる低い $m$ 值となり, $n$ 值も小さい と解釈できる。しかし $J_{\mathrm{cl}}^{\mathrm{c}} / J_{\mathrm{cl}}^{\mathrm{ab}}$ は，すべての試料に対して 磁場中熱処理によってその比が減少することが分かった. 前述したように，二方向電流分布モデルでは， $J_{\mathrm{cl}}{ }^{\mathrm{c}} / J_{\mathrm{cl}}{ }^{\mathrm{ab}}$ の 減少は, 結晶粒のアスペクト比の減少に起因していると解 釈することができる. Fig. 3 に示したように単芯テープ線 材に対する界面組織写真では結晶の微細化が見られてい る. 平板結晶の微細化はアスペクト比の減少に相当するの で，他の試料でも同様に結晶粒の微細化が起こっていると すると, これが, 磁場中熱処理による $n$ 值の増加の起源と 結論づけることができる．磁場中熱処理による結晶の微細 化については, さらなる研究が必要であるが, 例えば Y123 膜の磁場中成膜では, 結晶粒の微細化が観測されて いる ${ }^{10)}$. また, Bi2212 粉末に対する磁場中示差熱分析で
も, 結晶成長に関連する発熱ピークが磁場により変化する 現象も観測されており, 核生成エネルギーや結晶成長速度 の減少が磁場印加により起こっている可能性が示唆されて いる.

この様な磁場中熱処理を応用する場合は, 例えば超伝導 コイルを磁場中で熱処理する様なことが考えられる．この 場合, 丸線の場合には, Fig. 4, 5 に示したように, $J_{\mathrm{c}}$ と $n$ 值双方の向上が見込まれるが，テープ線材の場合でも， $n$ 值の向上が期待できる.テープ線材の $J_{\mathrm{c}}$ に関しては，多 芯化によるフィラメント厚の減少により, Ag 界面の効果 が大きいので, 印加磁場を最適化することにより， $J_{\mathrm{c}}$ を下 げずに, $n$ 值を向上するような条件を見出すことが可能と 予想できる. 実際, 単芯テープをテープ面に平行に磁場を 印加して熱処理を行った場合には， $J_{\mathrm{c}}$ は減少するが, $n$ 值 は向上する結果も得られている.

\section{4. まとめ}

本研究では，低温，強磁場中での応用が期待されている 種々の Bi2212 線材に対して磁場中熱処理を行い, 組織評 価， $E-J$ 特性の測定及びその解析を行った。これらの実験 結果から以下のようなことが分かった。

1 ）単芯テープの組織評価から, 磁場中熱処理によって Bi2212 結晶粒の $c$ 軸配向性が向上しただけではなく, 粒 径も減少したことが分かった。これは，Bi2212 に対する 磁場中熱処理が配向効果だけではなく, 結晶粒を微細化す る効果も持つことを示している.

2 ) 多芯丸線, 多芯テープ, 単芯テープのすべての試料に 対して, 磁場中熱処理によって $J_{\mathrm{c}}$ だけではなくこれまで Bi2212 線材で問題となっていた $n$ 值も向上することが分 かった. 磁場中熱処理による特性の向上は超伝導層の厚い 線材に対してより有効である.

3 ) パーコレーションモデルと二方向電流分布モデルを用 いた解析から，磁場中熱処理によって Bi2212 結晶粒のア スペクト比が減少することで $m$ 值の増大が起こり, $n$ 值 が向上することが分かった。したがって, 部分溶融法に よって作製される Bi2212 線材では, 必然的に結晶粒のア スペクト比が大きくなるために， $n$ 值が低くなるが，磁場 中熱処理はこれを改善できる有効な手段であることが分 かった.

\section{参 考 文 献}

1) H. W. Weijers, U. P. Trociewitz, K. Marken, M. Meinesz, H. Miao, and J. Schwartz: "Effects of conductor anisotropy on the design of $\mathrm{Bi}-\mathrm{Sr}-\mathrm{Ca}-\mathrm{Cu}-\mathrm{O}$ sections of $25 \mathrm{~T}$ solenoids, " Supercond. Sci. Technol. 17 (2004) 636-681.

2) H. Maeda, K. Ohya, M. Sato, W. P. Chen, K. Watanabe, M. Motokawa, A. Matsumoto, H. Kumakura and J. Schwartz: "Microstructure and critical current density of Bi2212 tapes grown by magnetic melt-processing, " Physica C 382 (2002) 33-37. 
3) D. C. Johnson and J. H. Cho: "Magnetic-susceptibility anisotropy of single crystal $\mathrm{Bi}_{2} \mathrm{Sr}_{2} \mathrm{CaCu}_{2} \mathrm{O}_{8}$, “ Phys. Rev. B 42 (1990) 87108713.

4) S. Pavard, C. Villard, D. Bourgault, R. Tournier:” Effect of adding $\mathrm{MgO}$ to bulk Bi2212 melt textured in a high magnetic field," Supercond. Sci. Technol. 11 (1998) 1359-1366.

5) K. Takahshi, S. Awaji, G. Nishijima, K. Watanabe and K. Togano: "E-J properties of Bi2212 tape in the practical current region," Supercond. Sci. Technol. 17 (2004) S568-S571.

6) K. Yamafuji and T. Kiss:" Current-voltage characteristics near the glass-liquid transition in high-Tc superconductors," Physica C 290 (1997) 9-22.

7) K.Takahashi et al:: "A new model of two directional $\mathrm{J}_{\mathrm{c}}$ distributions for $\mathrm{Bi}_{2} \mathrm{Sr}_{2} \mathrm{CaCu}_{2} \mathrm{O}_{8}$ materials," IEEE Trans. Appl. Supercond. 16 (2006) 1019-1022.

8) K. Watanabe, T. Inoue et al.: "Transport properties over critical currents for Ag-sheathed $\mathrm{Bi}_{2} \mathrm{Sr}_{2} \mathrm{CaCu}_{2} \mathrm{O}_{8}$ superconductors with different E-J dependence," Adv. Sci. Technol. 47 (2006) 118-123.

9) 淡路 智, 高橋健一郎, 渡辺和雄, 井上拓士 : Bi 系超伝導線 材の $n$ 值向上方法, 特願 2006-231547 (平成 18 年 8 月 29 日)

10) Y. Ma, K. Watanabe, S. Awaji and M. Motokawa: " $J_{\mathrm{c}}$ Enhancement of $\mathrm{YBa}_{2} \mathrm{Cu}_{3} \mathrm{O}_{7}$ films on polycrystalline silver substrates by metalorganic chemical vapor deposition in high magnetic field," Appl. Phys. Lett. 77 (2000) 3633-3635.

井上 拓士

昭和 57 年 12 月 6 日生. 2006 年 3 月東北大 学工学部応用物理学科卒業. 2008 年 3 月東北大学大学院工学研 究科応用物理学専攻博士前期課程修了. 主に高温超伝導材料の研 究に従事．同年 4 月より(株)本田技研工業勤務.

淡路 智昭和 40 年 7 月 15 日生. 昭和 63 年広島大学理学 部物理学科卒業. 平成 2 年同大学理学研究科物理学専攻博士課程 前
期修了. 同年 4 月より東北大学金属材料研究所に勤務. 同研究所 助手を経て, 現在同准教授. 主に超伝導材料の基礎物性研究およ び強磁場マグネットの開発に従事. 低温工学協会, 応用物理学 会, 日本金属学会, 工学博士.

高橋 健一郎昭和 52 年 10 月 27 日生. 2000 年東北大学工 学部応用物理学科卒業. 2005 年同大学大学院工学研究科応用物 理学専攻博士後期課程修了. 同年 4 月より東北大学金属材料研究 所博士研究員. 2006 年 5 月より物質 ・ 材料研究機構 博士研究 員, 低温工学協会, 応用物理学会会員. 工学博士.

Petre BADICA 1967 年 7 月 1 日生. 1996 年ウクライナ国立 技術大学 博士課程修了. 1996 年より現在まで, ルーマニア国 立材料物理研究所上級研究員, この間, 2000 年 -2002 年 産 業技術総合研究所博士研究員, 2002 年 -2003 年 物質材料研 究機構 特別研究員, 2003 年 -2005 年東北大学金属材料研究 所助手, 2005 年 -2007 年 東北大学金属材料研究所 特別研 究員. 学術博士.

西島 元昭和 45 年 3 月 10 日生. 1993 年東京理科大学 理学部応用物理学科卒業. 1998 年東京工業大学大学院総合理工 学研究科創造エネルギー専攻博士後期課程修了. 日本原子力研究 所博士研究員, 東北大学金属材料研究所 COE 研究員, 2001 年 8 月より東北大学金属材料研究所助手を経て, 現在同助教. 低温工 学協会, 応用物理学会, 電気学会会員. 工学博士.

渡辺和雄昭和 25 年 5 月 17 日生. 昭和 50 年東北大学理学 部物理学科卒業. 昭和 52 年同大学大学院修士課程(物理学専攻)修 了. 民間会社勤務を経て, 昭和 56 年 4 月から東北大学金属材料 研究所助手, 講師, 助教授. 平成 13 年 4 月から, 同研究所 教授. 低温工学協会, 日本金属学会, 応用物理学会, 日本磁気学 会, 日本磁気科学会会員. 工学博士. 